\title{
COMPLAINT STRATEGIES AND FORMULAS IN CAMEROON FRENCH: A CASE STUDY
}

\author{
Bernard Mulo Farenkiai \\ Cape Breton University, \\ Sydney, Nova Scotia, \\ Canada
}

\begin{abstract}
:
The present study examines the realization of complaints by Cameroonian French speakers. The data were collected, by means of discourse completion tasks (DCT) that was administered to 228 participants in Yaoundé and Douala, Cameroon. The examples were analyzed according to the following aspects: head act strategies (direct and indirect complaints) and external modifiers. With respect to head act strategies, the results show that the informants mostly preferred direct complaints in the form of expressions of disapproval and accusations, and indirect complaints in the form of expressions of disbelief and requests for repair. It was also found that the participants mostly used complex complaint utterances with a wide variety of pragmatic strategies and linguistic realizations. The analysis also reveals that the participants employed different types of external modifiers to soften or aggravate their complaints. These include preparatory acts such as exclamations, attention getters, address terms, etc., and supportive acts such as expressions of regrets, insistence acts, sarcasm, suggestions, etc. The strategies and formulas attested in the data seem to reflect the way in which Cameroon French speakers voice complaints in naturally occurring situations involving peer equality.
\end{abstract}

Keywords: complaint strategies, complaint formulas, Cameroon French

\section{Introduction}

From an interactional perspective, a complaint could be categorized either as a "direct" or an "indirect" act, based on the question whether the complaint in question is addressed to the person who committed the offense or not. While indirect complaints are expressions of dissatisfaction to an interlocutor about someone who does not take part in the verbal exchange or about something or circumstances (cf. Boxer 1993: 106), direct complaints are addressed to the person who actually committed the offense. Within the framework of speech act theory, complaints have generally been described as expressive speech acts, i.e. their illocutionary force is the expression of a psychological state about the speaker or the world: complaints are realized

'Correspondence: email bernard farenkia@cbu.ca, mulofarenkia@yahoo.fr 
to express annoyance, disagreement, disappointment, negative and unsatisfied feeling regarding a wrongdoing, or a certain state of affairs. According to Van Meenen (2016: 23),

"when a speaker voices a complaint, s/he expresses his/her dissatisfaction with a past or ongoing action, which is often done by asserting the negative state of affairs and by requesting repair, compensation or forbearance (...). Thus, speakers can have several intentions at the same time when formulating their complaints, so sometimes more than just one illocution is involved."

This perception concurs with Trosborg's view (1995:55) that "when a complaint is issued, a directive act may be implied or added in order to make the hearer repair the damage s/he has caused, or prevent a repetition of the deplorable act." Direct complaints and indirect complaints also differ with respect to their impacts on interpersonal relationships. While indirect complaints, which are also called acts of gripping, typically serve to establish solidarity in social interaction or to seek sympathy or commiseration from hearer (see Boxer 1993; 2010), direct complaints typically threaten the face of the interlocutor and the social relationship. Our focus, in the present study, is on direct complaints, which Trosborg (1995: 311-312) defines as follows:

"the speech act of complaint belongs to the category of expressive functions. This category includes moral judgements which express the speaker's approval as well as disapproval of the behaviour mentioned in the judgement. [...] in a complaint, the events described in the proposition took place in the past [...]. The act of complaining is in essence retrospective in that a speaker passes a moral judgement on something which (he/she believes) the complainee has already done or failed to do, or is in the process of doing. [...] A complaint is (...) an illocutionary act in which the speaker (the complainer) expresses his/her disapproval, negative feelings etc. toward the state of affairs described in the proposition (the complainable) and for which he/she holds the hearer (the complainee) responsible, either directly or indirectly."

Direct complaints belong to the category of conflictive acts such as threatening, accusing, cursing, and reprimanding (Leech 1981). They are face-threatening acts (Brown and Levinson, 1987) as they are performed in order to dispute or challenge the social competence of the addressees, to describe their action as "socially unacceptable", therefore hurting their feeling and threatening the social relationship between speaker and hearer.

\section{Research on complaints}

The speech act of complaining has been examined extensively. While some of the studies focus on complaint strategies in individual languages such as American English (Boxer, 1996a, Hartley, 1998), Chinese (Du, 1995), Peruvian Spanish (Garcia, 1996, 2009), German (Gunthner, 2000), others look at the realisation of complaints by second language learners (cf. Olstain, \& Weinbach, 1987; 1993; Murphy and Neu, 1996; Boxer, 1996b, Trosborg, 1995; Meyer, 2007; Kraft and Geluykens, 2002, Shaeffer, 2018). Extensive studies also exist on complaints from a cross-cultural pragmatics perspective (cf. Kraft and Geluykens, 2008, Siebold, 2009; Chen et al., 2011; AlKhawaldeh, 2016; Essien Otung, 2019) or from a variational pragmatics perspective (cf. Rinnert 
\& Iwai, 202). A review of studies on the act of complaining is offered by Chen et al., 2011: 256258. Few studies focusing on "electronic complaints", i.e. those made in computer mediated communication, are also available (see Vasquez, 2011; Meinl, 2014; van Meenen, 2016, Marchand, $\left.2016^{i i}\right)$. Most of the studies on complaints in French focus on the varieties of French spoken in Canada (Laforest, 2002) and France (Traverso, 2008 ${ }^{\mathrm{iii}}$ ).

Many studies have established that "complaints are very variable in form" and that it is "often impossible to distinguish [them] from closely related speech acts such as disapproval, criticism, accusation, etc. as distinct from one another" (Meinl, 2018: 17). As a matter of fact, it was found in many empirical studies that most complaints occur in the form of these closely related speech acts. With respect to the types of utterances used to complaint, it is widely accepted that complaints are realized either as a simple turn or as a complex turn. In a simple complaint turn, a single speech act is used to voice the complaint. In a complex complaint turn, the speaker voices their complaint using a combination of two or more utterances. In this case, the complainer produces a speech act set, communicative act, or combination of several speech acts/moves to express his or her displeasure. The choice of specific speech acts to realize complaints and the choice of single or complex complaint utterances depend on a number of factors, including social distance (degree of familiarity between the interlocutors), power distance (social or institutional status of the interlocutors), the severity of the offensive action/behavior that triggered the complaint, and politeness considerations in the social context where the interaction is taking place.

The present study is conducted within the framework of postcolonial pragmatics. It examines complaints in an ex-colonial language in Cameroon, a postcolonial society where two official languages, French and English, are permanently in contact with more than 250 native languages. It factors in the way in which the complex, multilingual, multiethnic and multicultural postcolonial nature of the Cameroonian society influence the linguistic forms and pragmatic strategies chosen by members of the community when voicing their complaints. For instance, the types of preparatory acts attested (e.g. address terms, exclamations, attention getters), the realization patterns used in the complaint utterances could be said to be, in some extent, reflections of local norms and the sociolinguistic context governing verbal exchanges in Cameroon. The speech act of complaining in Cameroon French is considered here as a postcolonial pragmatic behaviour. The next section reports on the methodology employed. The findings of the study are presented and discussed in section 4 . Section 5 summarizes the main outcomes of the study and mentions some avenues for future research.

\section{Methodology}

\subsection{Data collection and participants}

The complaints were elicited using a discourse completion task (DCT) questionnaire (cf. BlumKulka et al. 1989), consisting of several everyday situations in which the participants were asked to realize different types of speech acts. Each scenario comprised a brief description of the setting, i.e. "the general circumstances [...] and the relevant situational parameters concerning social dominance,

\footnotetext{
ii A cross-cultural pragmatic study of customer complaints on the tweeter profiles of the German Railway Cooperation (Deutsche Bahn) and the French Railway Cooperation (SNCF).

iii The study focuses on indirect complaints or "third-party complaints".
} 
social distance and degree of imposition" (Barron, 2008: 43). The present study focuses on one complaint situation involving two friends. The situation was described as follows:

"Votre meilleur(e) ami(e) e emprunté votre plus belle et plus chère veste. Quand illelle vous la redonne, vous trouvez qu'il y a un grand trou au dos. Vous lui dites:" 'Your best friend has borrowed your favourite and very expensive jacket. When he/she returns it, you discover a big hole in the back. You say to him/her:'"

As can be seen in this scenario, this situation represents an informal situation where the speaker (the complainant/complainer), and the addressee (the offender) are close friends and equal in social status. The severity of the offence seems to be very high.

Data collection took place in Yaoundé and Douala, Cameroon, in two phases. The first collection took place in 2013, with 148 students of the University of Yaoundé I and the University of Douala (100 females and 48 males), aged between 18 and 30 years, participating in the study. The second phase took place in 2015, with 80 students (64 females and 16 males) of the University of Yaoundé I, aged between 18 and 30 years, participating in the study. In total, 228 respondents (164 (71.9\%) females and $64(28.1 \%)$ males) took part in the study. The majority of these informants, i.e. $179(78.5 \%)$, were aged between 20 and 27 years. It is also important to note that all the participants acquired French through school education and, at the time of the data collection, they had been speaking French for more than 15 years alongside other languages and/or language varieties. Traces of the complex sociolinguistic and cultural background of the participants can be identified in their speech act realization strategies.

\subsection{Data analysis}

The examples provided by the informants represented complaints which appeared alone (head acts), were repeated (multiple head acts) (cf. Section 4.2), or accompanied by other types of speech acts utterances (head acts + external modifiers) (cf. Section 4.3). The analysis of the types of utterances used by the informants in realizing complaints, the strategies that they preferred when voicing complaints, and the pragmatic intents behind the strategies chosen, was carried out in many steps.

The first step was to examine the structure of complaint utterances according to the degree of complexity and the number of moves used to realize a complaint. The results show that some respondents produced simple complaints i.e. those expressed using single speech acts, while others preferred complex complaints i.e. those made up of several acts/moves. Examples of simple complaints include Je ne suis pas fier de toi. 'I am not happy with you' ; Merci de m'avoir remis ma veste en bon état. 'Thanks for returning my jacket in good shape.' Simple complaint utterances are head acts, i.e. communicative units that realize complaints independently of any other unit of a conversational turn. Complex complaints result from combinations of two moves as in (1) or more than two moves as in (2).

1) Je ne savais pas que tu étais aussi négligent! Désormais, tu ne m’emprunteras plus jamais mes habits.

'I didn't know that you were so careless! Henceforth, you will not borrow my clothes.' 
2) Gars, comment tu peux me faire cela ? Je te prête ma veste en bon état et tu me le remets en piteux état. Lorsqu'on vous refusera certaines choses vous allez dire que l'homme est méchant. 'Man, how can you do this to me? I lend you my jacket in good shape and you return it in a pitiful shape. If I refuse to lend you certain things in the future you will say that I am wicked.'

In (1), the head act (boldfaced) is used to express the speaker's disappointment about the interlocutor's negligence. It is followed by a supportive act (underlined) by which the speaker announces his decision to not lend his clothes again to the addressee. The pragmatic function of this supportive act is to aggravate the illocutionary force of the head act. In (2), the complaint (in boldface) is indirect as it is performed using an interrogative utterance, in which the expression faire cela makes reference to the addressee's negligence. The head act is followed by a comment (underlined) on or a description of 'the interlocutor's negligence and the damage caused on the jacket. More precisely, the speaker seeks to highlight to the following contrast: the jacket was in very good condition (en bon état) when the interlocutor borrowed it and. Currently, it is in a very poor condition (en piteux état). By highlighting this contrast, the speaker indirectly accuses the interlocutor of negligence. The complainer goes on to issue an indirect warning regarding potential consequences of the addressee's action. The indirectness here is materialised by the use of the pronouns on and vous and the term l'homme to pre-empt any attempt to consider the speaker as wicked person if he refuses to lend his clothes next time. In such examples, I refer to moves that appear after the head acts (post head act speech acts) as supportive acts. The supportive acts may either reinforce or mitigate the illocutionary force of the head acts. Examples in the corpus also show that different types of speech moves occurred before the head acts. I refer to them as pre-complaints or preparatory acts. Different types of pre-complaints were found in the examples (cf. Section 4.3.1). They appeared alone or in combination with other preparatory acts, as can be seen in (3-4).

3) Mama, je demande hein! Tu as la lame au dos? Tu sais combien cette veste m'a cô̂té? Franchement hein je suis déçue. Je ne ferai plus cette erreur-là!

'Mama, let me ask you this! Do you have a razor on your back? Do you know how much this jacket cost me? I am really disappointed. I will not make the same mistake (next time).

4) Mais Ariane, c'est comme cela que je t'ai remis ma veste hein? Tu sais combien elle m'a cô̂té non? Je te donne ma chose et toi tu pars la gâter. Merci beaucoup!

'But Ariane, is this in this shape in which I gave you my jacket hein? You know how much it cost me, don't you? I lend you my property and you destroy it. Thanks a lot!

In (3), the third utterance (in boldface) is an expression of disappointment. It could be considered as the head act of the speech act set. The two preceding moves (underlined) are precomplaints with various pragmatic functions. The first of them is a combination of an exclamation or address term (mama) and an attention getter (je demande hein). It is used to catch the attention of the interlocutor. The second pre-complaint is a question which serves to express 
the speaker's unpleasant surprise. ${ }^{\text {iv }}$ The third move (boldfaced and underlined) is an indirect complaint: it is used to introduce and reinforce the direct complaint (in boldface). The direct complaint is followed by a supportive move in which the speaker vows not to make the same mistake in the future or not to lend her jacket anymore.

In (4), the head act (in boldface) is an explicit blame or accusation. It is preceded by an interrogative utterance (boldfaced and underlined) by which the speaker expresses her unpleasant surprise and appeals to the hearer's moral consciousness. Interesting here is the use of the discourse markers non at the end of the interrogative structure to request for confirmation. The speaker is telling the interlocutor that she should be aware of the value of the jacket in question. As already indicated in the previous example, the indirect complaint serves to announce the direct complaint. The two pre-complaints (underlined) have various pragmatic functions: the first one is made up of an interjection (mais) and a first name (Ariane) and they are employed to get the hearer's attention and to express surprise/disbelief; the second one is a question. The discourse marker (hein) at the end of the question serves to put pressure on the interlocutor. The head act is followed by an expression of gratitude which in this context should be interpreted as sarcastic.

As can be seen from the examples discussed above, external modifiers, i.e. preparatory and supportive acts, are not obligatory. We also noticed that complaint turns also consisted of multiple head acts (repetition of complaints or compound complaints), as in (5), where the speaker combines three direct complaints, two expressions of disappointment (in boldface) and one expression of disapproval (underlined). Instances of compound complaints could be said to be a pragmatic strategy used to aggravate the complaint and threaten the face of the addressee. In examples where many head acts occur, it is also possible to consider one move as the core component (head act) and the others as external modifiers, i.e. supportive moves.

5) Je ne suis vraiment pas contente de toi [DISAPPOINTMENT]. Ce n'est pas gentil ce comportement [DISAPPROVAL]. Je suis déçu [DISAPPOINTMENT].

'I am really not happy with you. This type of behaviour is not nice. I am disappointed.'

In complex complaint turns, head acts occurred at the beginning of the turn followed by supportive acts or in the middle preceded by one or more pre-complaints and followed by one or more supportive acts.

The head acts were also examined with respect to their level of directness. The analysis at this level was intended to determine whether a head act is realised directly as in (6) or indirectly as in (7). In (6), the speaker makes use of a reprimanding act to complaint about the addressee's action, while the speaker in (7) announces that he or she will no more lend his/her clothes to the interlocutor as way to express his or her dissatisfaction or annoyance. ${ }^{v}$

6) Tu devrais faire plus attention aux affaires personnelles des autres quand tu les empruntes. 'You should take good care of others' personal belongings when you borrow them.'

\footnotetext{
iv The utterance $T u$ as la lame au dos? can also function as an indirect complaint, when it occurs alone or in combination with supportive acts (e.g. Tu as la lame au dos? Je ne te donnerai plus jamais mes habits.)

v For a description of direct and indirect complaint strategies, see Trosborg (1995: 315-322).
} 
7) Que ce soit la dernière fois que je te prête un de mes vêtements!

'Let this be the last time that I lend you one of my clothes.'

Overall, the respondents used a wide range of pragmatic strategies and linguistic forms to voice their complaints. Section 4 presents and discusses the results of the analysis: the components of the complaint utterances in the data are described with respect to their frequencies, realisation patterns, and pragmatic functions.

\section{Results and discussion}

\subsection{Overall distribution of strategies}

The respondents used 552 strategies to frame their complaints: these consist of head acts and external modifiers (i.e. preparatory acts and supportive acts). Their distribution is summarized in Table 1. As we can see, the respondents mostly used head acts, these account for $70.6 \%(n=390)$ of the utterances. The distribution of external modifiers shows that preparatory acts are the second recurrent components found in the examples (they represent $15.6 \%(n=86)$ of the examples), while supportive acts occur 76 times (13.8\%).

Table 1: Distribution of head acts and external modifiers (preparatory and supportive acts)

\begin{tabular}{|c|c|}
\hline Type of strategy & No (\%) \\
\hline Head acts & $390(70.6 \%)$ \\
\hline External modifiers & $162(9.4 \%)$ \\
\hline a. Preparatory acts & $86(15.6 \%)$ \\
\hline b. Supportive acts & $76(13.8 \%)$ \\
\hline Total & $\mathbf{5 5 2}(\mathbf{1 0 0} \%)$ \\
\hline
\end{tabular}

\subsection{Head act strategies}

This section describes the types of head acts used by the participants, focusing on the strategies used to complaint and the pragmatic functions of these strategies. In terms of level of directness of the complaints, the respondents produced direct as well as indirect complaints. They were realized using different types of strategies. ${ }^{\mathrm{vi}}$ With respect to the content or focus of the complaints issued, the following types of complaints emerged:

- Complaints that highlighted the speaker's dissatisfaction, annoyance, accusation, disappointment, etc.

- Complaints that focused on the reasons for the complaint.

- Complaints that stressed the consequences of the speaker's disappointment.

The complaint realisation patterns included aspects such as disapproval, criticism/moral judgement, accusation, reprimand, insults, sanctions, etc., and most of these strategies did not appear alone, but rather they were used in combination with preparatory and supportive acts. In many cases, two different complaint strategies or head acts occurred in the same complaint turn as in (8), where an expression of disapproval (in boldface) combines with allusion to a

\footnotetext{
vi They rarely appeared alone in the data. There were only 13 (7.5\%) occurrences of complaints appearing as a single act (simple complaints).
} 
sanction (underlined). Table 2 presents the distribution of the complaint strategies found in the data.

8) Je ne suis pas du tout fière de toi pour ce geste. Prochainement je ne te donnerai plus ma veste. 'I am not happy at all with you because of this gesture. Next time I will not give you my jacket anymore'.

Table 2: Distribution of complaint strategies

\begin{tabular}{|llc|}
\hline Head act type - Complaint strategy & Frequency \\
\hline 1. & Expressing surprise/disbelief (through questions) & $120(30.8 \%)$ \\
\hline 2. & Expressing disapproval or disagreement & $75(19.2 \%)$ \\
\hline 3. & Expressing threat - Alluding to sanctions & $47(12 \%)$ \\
\hline $4 . \quad$ Expressing accusation - Alluding to offensive action & $41(10.5 \%)$ \\
\hline 5. & Requesting repair or replacement & $41(10.5 \%)$ \\
\hline 6. & Criticizing / Reprimanding - Requesting change of behaviour & $32(8.2 \%)$ \\
\hline 7. & Rejecting damaged jacket and/or offering it to addressee & $18(4.6 \%)$ \\
\hline 8. & Stressing severity of damage & $16(4 \%)$ \\
\hline Total & $390(100 \%)$ \\
\hline
\end{tabular}

As Table 3 shows, the participants used many different strategies to realize their complaints. The most preferred strategy consisted in expressing surprise or disbelief, mostly through interrogative constructions. It represents 120 occurrences, accounting for $30.8 \%$ of all complaint strategies. The second most frequent strategy was the expression of dissatisfaction, i.e. disapproval of or disagreement with the addressee's action, which appears 75 times, representing 19.2\%. The third complaint strategy was expressing threat or alluding to sanctions, which accounts for 47 instances (12\%) of all complaint strategies. Accusations (10.5\%), and requests for repair or replacement $(10.5 \%)$ were the next most frequently used strategies. The remaining strategies occurred with lower frequencies. These include criticizing/reprimanding or requesting change of behaviour (8.2\%), rejecting jacket and/or offering it to addressee (4.6\%) and stressing the magnitude of damage caused (4\%). All the strategies attested in the data have specific pragmatic functions and they have different realisation patterns, as will be discussed in the following sections. While strategies such as "expressing disapproval/disagreement" and "expressing accusations" could be considered as direct complaint strategies, strategies such as "expressing disbelief (through questions)", "requesting repair/replacement", "stressing severity of damage caused" could be interpreted as indirect complaint strategies. It is clear from the Table above that the respondents mostly used strategies that expressed their disapproval of or negative feelings concerning the state of affair mentioned in the proposition. Also noteworthy is the fact that complaints were aggravated or mitigated by means of internal or external modification devices.

Let us now turn to the various types of head acts or complaint strategies, their pragmatic functions and realization patterns in the corpus. In cases of complex complaint utterances, bold font will be used to highlight the strategy being illustrated. 


\subsubsection{Expressing surprise or disbelief (through questions)}

This strategy, the most frequently used, serves to point at the offensive action, to express speaker's surprise and to explicitly mention the addressee as the author of the offence. The impact of the complaint is thus intensified (cf. House and Kasper 1981: 170). Disbelief or negative surprise was mostly expressed by means of interrogative constructions. This strategy is employed "when the complainer presupposes that the complainee is guilty of offense and questions him/her about the offense" (Chen et. al, 2011: 260). In other words, it is a "way of pointing out that the speaker recognizes the hearer has committed an offensive act [....]/ The complaint is disguised as a request for information [and] it is not likely that the speaker is really interested in an answer to the question but rather is using this as a way of presenting a complaint" (Hartley, 1998: 82). This strategy was mostly realized using interrogative constructions with the following morpho-syntactical features:

- Qu'est-ce que / qu'est-ce qui (e.g. Je demande hein. Qu'est-ce que t'as fait avec ma veste comme ça ?'I ask eh. What did you do to my jacket?')

- Comment (e.g. Comment tu peux être négligent comme ça ? Je n'ai plus besoin de cette veste garde la. 'How can you be this negligent. I don't need this jacket anymore. Keep it.').

- Pourquoi (e.g. Mais qu'est-ce qui s'est passé avec la veste? Et pourquoi n'as-tu pas fait l'effort de la raccommoder avant de me la remettre? 'What happened with my jacket? And why didn't you try to mend it before returning it?')

- Quel / quelle (e.g. Qu'elle est cette manière d'entretenir les vêtements ? Tu n'auras plus une faveur de ma part, c'est la fin. 'What is the way of handling clothes? You will not have any favor from me again. That's it.').

- C'est (encore) quoi/quel/quelle + NP + comme ça? (e.g. Mais gars, c'est encore quel modèle ça ?'Man, what type of behavior is this ?' C'est encore quoi comme ça? 'What is this ?')

- Ça c'est quel/quelle + NP + comme ça ? (e.g. C'est quelle façon comme ça? 'What type of behavior is this?')

- C'est comme ça que + VP ? (e.g. Je demande hein, c'est comme ça que je t'ai donné mon vêtement? 'I ask eh, was my jacket in this shape when I gave it to you?')

Also attested are Yes-No-questions, which in most cases, were introduced by one or more of pre-complaints (cf. Section 4.3.1), as illustrated in (9).

9) Mama! Je demande hein! Tu as la lame au dos ? Tu sais combien cette veste m'a cô̂té? Franchement hein je suis déçue. Je ne ferai plus cette erreur-là!

'Mama, I as eh. Do you have razor blade on your back? Do you know how much this jacket cost me? I am really disappointed. I will never make this type of mistake again.'

This complaint turn has two head acts. The first one appears in the form of a rhetorical question about the price or value of the damaged jacket. The speaker uses this strategy to express her disapproval of the interlocutor's behaviour and to stress its severity. The indirect complaint is reinforced by a much more direct complaint, an expression of disappointment (Franchement hein je suis déçue), which is intensified by means of the adverb franchement and the marker hein. The two complaints are preceded by a combination of an exclamation (mama), an attention getter (je demande hein) and an expression of negative surprise (tu as la lame au dos?). The complaints are followed by an allusion to potential consequences of this incident: the speaker is determined not 
to make the same mistake in the future, indirectly announcing she will not lend her jacket to the addressee again.

Another realization pattern of the expressing disbelief strategy was the use of declarative constructions with verbal clauses such as Je n'en reviens pas. 'I can't believe.' Je ne savais pas que. 'I didn't know that." (e.g. Je ne savais pas que tu étais aussi négligent. 'I didn't know you were so negligent.'). The realization pattern was used in very few cases.

\subsubsection{Expressing disapproval, disagreement or disappointment}

In order to voice their disapproval of or disagreement with the addressee's action, the participants used negative loaded constructions (e.g. Je ne supporte pas ce que tu as fait. 'I cannot stand what you have done.' Je n'aime / n'apprécie pas ça. 'I don't like it/that' Je ne suis pas contente (de toi). 'I am not happy (with you).' Je suis déçu/fâché. 'I am disappointed/angry.' Je suis en colère. 'I am angry.' Ça m'énerve. 'It annoys me.' Je t'en veux. 'I blame you.' Tu me déçois. 'You disappoint me.' Je ne peux/veux pas comprendre cela. 'I can't/ don't want to understand that.') The respondents also used constructions with negatively loaded adjectives or nouns by which they criticize the addressee's action or attitude. Most of the constructions attested begin with expressions such as C'est le/la, Ça c'est, Ce n'est pas/C'est pas which refer to the offence committed (e.g. Ce n'est pas / C'est pas sérieux/gentil/juste. 'This is not nice/fair.' C'est irresponsible. 'This is irresponsible.' C'est vraiment ingrat de ta part. 'This is really ungrateful of you.' C'est le mauvais caur. 'This is wickedness.', Ça c'est de la pure négligence. 'This is sheer negligence.') Also attested were constructions by which the speaker described the offence (e.g. Tu ne respectes pas la chose d'autrui. 'You do not respect/care about another person's property.' Tu as trahi ce peu de respect qui pouvait encore exister. 'You betrayed the little respect I could have for you.') or the negative impact of the offence (e.g. Tu m'as seulement tué. "You have just killed me.') Overall, these constructions were combined with other strategies as in (10-11).

10) Je suis en colère contre toi. Sache que tu vas la remplacer.

'I am angry with you. Know that you will replace it.'

11) Ce n'est pas sérieux ce que tu as fait. Arrange-toi à me la remettre comme telle c'est-à-dire intacte.

'It is not nice what you have done. Make sure you return it as it was initially, that is to say in good condition.'

\subsubsection{Expressing threat / Stating negative consequences of the offence}

With this strategy the complaint came through as an announcement of potential or effective sanctions against the hearer. The informants issued treats or warnings concerning future interactions with their friends in general and regarding lending of belongings in particular. They indicated, for instance, that they would no longer lend their clothes or properties to their careless interlocutors. This complaint strategy appeared alone or in combination with other strategies. Used alone, it functioned as an indirect complaint. In association with other strategies, such threats or warnings served as supportive acts. Many realization patterns were found in the data. 
Some respondents simply warned the interlocutors that the offensive action would not be tolerated in the future, using a construction like La prochaine fois je ne l'admettrai pas. 'Next time I won't accept it/I won't be lenient.' Other participants vowed either not to lend their jacket or any piece of their belongings to the interlocutor again, uisng constructions like Que ce soit la dernière fois que je te prête un de mes vêtements. 'Let this be the last time that I lend you one of my clothes.' Dorénavant je ne te donnerai plus mes choses. 'Henceforth I will not lend you my belongings.', or not to make the same mistake in the future, using constructions like Je ne ferai plus cette erreurlà. 'I will not make that mistake again'. Some of the informants vehemently forbade their interlocutors to ask them for clothes or other properties using negative imperative structures (e.g. Ne reviens plus jamais solliciter mon aide. 'Never come again to ask for my help.').

\subsubsection{Expressing accusation}

This was the fourth most common complaint strategy in the data. It was employed to mention the offensive act or behaviour of the interlocutor and to highlight its consequences on the speaker's jacket. Different were used patterns to realize this strategy. Some participants used negative loaded assertive utterances to describe the offensive action and its consequences (e.g. Vous avez endommagé ma veste. 'You have damaged my jacket.' Tu m'as abimé ma plus belle veste 'You have damaged my best jacket.'). Other informants employed constructions that described the offensive action (e.g. Je constate que tu n'as pas bien conservé mon vêtement. 'I notice that you did not handle my jacket well.') or the state of the jacket without mention of the interlocutor (e.g. Ma veste a un grand trou. 'My jacket has big hole.' Tiens, il y a un grand trou au dos. 'Look, there is a big hole in the back of the jacket.'). Imperative utterances with or without explicit negative evaluation were also used to present evidence that the offense took place (e.g. Regarde comme tu l'as abimée. 'Look how you have damaged it (my jacket).' Gars toi-même regarde dans quel état est ma veste. 'Guy, look at the condition in which my jacket is.').

\subsubsection{Requesting repair or replacement}

This complaint strategy was employed by participants to express disappointment concerning their interlocutors' behaviour / action and to ask the latter for repair or replacement. Some informants used declarative constructions to indicate or suggest a line of action that would remedy the situation. They employed expressions of obligation or necessity with il faut in the indicative or conditional (e.g. Il faut aller chez la couturière. 'You have to go to the seamstress.' Il faut te débrouiller 'You have to find a solution.' Il faudra qu'on achète une autre veste. 'We will have to buy another jacket.') or the verb devoir in the indicative or conditional (e.g. Tu dois arranger la situation. 'You have to fix the situation.' Tu devrais me la rendre en bonne et due forme. 'You should return my jacket in good shape.')

The respondents also used constructions with (modal) verbs in the present or future tenses to intensify the requests made (e.g. Tu me donnes une autre veste. 'You will give me another jacket.' Tu vas que m'acheter une autre veste. 'You will buy me another jacket. You have no choice.' Je veux ma veste sans trou. 'I want my jacket with no hole.') Requests for repair also appeared in the form of suggestions (e.g. Je te suggère d'aller m'en acheter une autre. 'I suggest that you go buy me another jacket.'). 
In many cases, the requests for repair or replacement were intensified by using clauses at the beginning or at the end of the requests: these include sache que, je ne veux rien entendre, peu importe ce que tu dois faire, pardon, je suis désolé, je t'assure (e.g. Sache que tu vas la remplacer. 'Know that you will replace it.' Tu vas me la rendre, je t'assure. 'You will replace it, I assure you.' Tu vas $m^{\prime}$ acheter une autre veste. Je ne veux rien entendre. 'You will buy me another jacket. I don't want to hear anything else.') Other intensifying devices include negatively loaded expressions such as ce trou monstrueux, comme ça, dans un tel état and adverbs such as seulement (e.g. Tu vas la remplacer seulement. You will just have to replace it.'). The use of verbs in the present or future tenses also served to indicate that the complainers were not joking and that there would be no other option to consider.

Comparative clauses were also used to stress the type of repair or restitution requested from the offender. Some participants requested restoration of the jacket to its former condition (e.g. l'état où elle était lors que tu l'as prise, en parfait état, en bonne et due forme, veste intacte, veste sans trou), while others requested a completely new jacket (e.g. une nouvelle veste, une autre plus jolie et plus chère, un autre vêtement, veste toute neuve). Mitigation of requests occured through the use of address terms (e.g. cher ami, chère amie, gars), politeness makers (e.g. s'il te plait), and hedging expressions like je pense que, tu devrais, je te suggère de, je souhaiterais que.

\subsubsection{Criticizing / Reprimanding / Requesting behaviour change}

By using this strategy, the informants intended to invoke some general moral or societal norms that their interlocutors were not able to respect. This complaint strategy mostly occurred in constructions containing verbs in the conditional such as tu aurais dîu (e.g. Tu aurais dî bien garder ma veste. 'You should have handled my jacket well.'), tu pourrais au moins (e.g. Tu pourrais au moins exprimer ta désolation. 'You could at least say you are sorry.'), tu devrais (e.g. Tu devrais faire plus attention aux effets personnels des autres quand tu les empruntes. 'You should be more careful about people's belongings when you borrow them.'). Criticisms appeared with other types of strategies as in (12): the criticism (boldfaced) is preceded by an expression of disappointment and followed by an announcement that the speaker will not lend anything again to the addressee.

12) Je ne suis pas contente. Tu aurais dî prendre soin de ma veste comme la tienne. Crois-moi c'est bien la dernière fois que je te prête quelque chose.

'I am not happy. You should have taken care of my jacket like yours. Believe me this is the last time I will lend you something.'

Advice giving / moralizing was realized uisng constructions like Quand quelqu'un te donne sa chose il faut en prendre soin. 'If someone lends you their thing you have to take care of it.' Si tu prends la chose de quelqu'un un jour et tu constates qu'il y a des choses pareilles, il faut quand même arranger avant de lui donner. 'If you borrow someone's thing and notice a problem with it you should fix all the same it before returning it.'

To voice their complaints, some participants requested change of behaviour using declarative constructions (e.g. J'espère que prochainement tu feras un effort. 'I hope that next time you will make an effort (to take care of it).' Tu dois être capable de prendre soin de mes affaires comme si c'étaient les tiennes. 'You have to be able to take care of my properties as if they were yours.' 
C'est à toi d'être responsable. 'You have to be responsible.'), imperative constructions (e.g. La prochaine fois, fais attention. 'Pay attention next time.' Tâche de bien garder mes choses la prochaine fois/ 'Try to take good care of my belongings next time.' Apprends à entretenir les choses d'autrui comme si c'étaient les tiennes. 'Learn how to look after people's things as if they were your own.') and/or proverbial constructions (e.g. Qui endommage dédommage. Tu ferais mieux soit de me rembourser ou de m'acheter une nouvelle veste. 'Who damages compensates. You better either pay me back or buy me a new jacket.')

\subsubsection{Offering damaged jacket to addressee / Refusing damaged jacket}

In order to express their disappointment, some respondents simply refused to take back the damaged jacket. Instead, they offered it to or asked their interlocutors to keep it. Such offers/refusals were realized using imperative constructions (e.g. Garde-la (pour toi)., Reste avec. 'Keep it.') and declarative constructions (e.g. Tu peux garder cette veste. 'You can keep the jacket.' Je t'en fais cadeau. 'I am giving it to you.' Il vaut mieux que tu restes une fois pour toute avec. 'It is better that you keep it once and for all.' Tu peux la garder si tu veux ». 'You can keep it if you want to.' Although this strategy alone could be used to voice disappointment, it did not occur alone in the data. It was associated with other types of strategies, among which justifications by which the speakers stressed the uselessness of the jacket in the current condition, as in (13).

13) Je préfêre que tu la gardes. Elle ne me sera plus d'aucune utilité.

'I prefer that you keep it. It will no longer be of use to me.'

\subsubsection{Stressing the severity of damage caused}

Some participants voiced their complaints by stressing the current bad condition of the jacket as a consequence of the addressee's negligence. They mostly drew a contrast of the condition of the jacket before and after the interlocutor borrowed it. As we can see in the examples (14-15), this strategy was associated with other complaint strategies.

14) Non Robert, ce n'est pas comme ça que je t'ai remis ma veste. Trouve une solution par rapport à ça.

'No Robert, this is not the jacket I handed to you. Find a solution to that.'

15) Quand je t'ai prêté ma veste, elle était en bon état donc rends-la moi en bon état.

'When I lent you my jacket, it was in good condition so give it back to me in good condition.'

After discussing realisation strategies of head acts found in the data and the pragmatic functions of these strategies, let us examine the types of supportive moves or external modifiers used by the respondents to soften or aggravate their complaints.

\subsection{External modifiers}

Two categories of external modifiers were found in the data: preparatory acts and supportive acts. Preparatory acts were employed to introduce/prepare the head acts. As the discussion 
below shows, these preparators generally served either to break the ground or warn the interlocutor that a complaint is forthcoming (cf. Trosborg, 1995: 330). Supportive acts were all the speech acts that appeared after the head acts.

\subsubsection{Preparatory acts}

The 86 preparatory acts attested in the examples belong to four categories, as seen in Table 3. They are nominal address terms, exclamations, questions/expressions of surprise, and attention getters. These acts were used either alone, i.e. as independent pre-head acts, or in combination with other preparatory acts, thus generating complex pre-complaints or preparatory acts.

Table 3: Distribution of preparatory acts

\begin{tabular}{|l|c|}
\hline Type of preparatory act & Frequency \\
\hline Nominal address terms & $28(32.5 \%)$ \\
\hline Exclamations & $25(29 \%)$ \\
\hline Attention getters & $22(25.6 \%)$ \\
\hline Expressions of surprise - Appeals to interlocutor's conscience & $11(12.8 \%)$ \\
\hline Total & $\mathbf{8 6}(\mathbf{1 0 0} \%)$ \\
\hline
\end{tabular}

\subsubsection{Nominal address terms}

The participants employed 28 nominal address terms (single terms and compound terms), namely friendship terms (e.g. gars mon amie, mama, ma grande), kinship terms (e.g. ma sœur, mon frère), endearment terms (e.g. mon cher ami, chère amie, ma personne, ma très chère amie), and first names (e.g. Ariane, Jacques). These terms were employed a) to capture the addressee's attention, who might not be aware of any problem with the jacket or be distracted by something else; $b$ ) to remind the friendly relationship between the speaker and the addressee before making the complaint, as in (16). In this example, the address terms could be interpreted as a way to soften the complaint Tu n'es pas gentille. 'You are not nice.' The repetition here serves as mitigator for the complaints. The speaker is trying to say that the friendship is maintained despite the damage caused.

16) Ma sour et ma très chère amie, tu n'es pas gentille. Regarde ce grand trou. Pourquoi tu m'as fait ça? Tu sais bien que c'est ma dernière valise et que je n'ai plus d'argent.

'My sister, my very dear friend, you are not nice. Look at this hole. Why did you do this to me? You know well that it is my best piece of clothing and that I have no more money.'

\subsubsection{Interjections / Exclamations}

Overall, 25 exclamations were used to express (unpleasant) surprise and/or to catch the hearer's attention prior to the complaint. The participants employed simple exclamations (e.g. merde, putain, oh, mince, wee, ah, dis-donc, tiens, mais, non) as well as complex exclamations (e.g. C'est pas possible, Oh quel dérangement, Oh la vache, Non mais, Non non non, Oh mon Dieu, Quelle malchance, Toi aussi, Je savais). 


\subsubsection{Expressions of surprise / Appeals to addressee's conscience}

The informants made use of these pre-complaints to express surprise or to appeal to the moral consciousness of their friends. The following expressions were found in the data: C'est quoi ça, Ça c'est quoi ça? C'est comment? C'est une blague ou quoi ? Je vois mal ou quoi ? C'est how ? Qu'est-ce que ça veut dire (ça)? Mais qu'est-ce que c'est? An illustration is given in (17): The pre-complaint (in boldface) is a combination of the interjection mais and the interrogative construction qu'est-ce que $c^{\prime} e s t$ que ça? that serves as expression of surprise. The head act is realized in the form of an accusation (Tu as osé abimer ma plus belle veste!) and it is followed by a request for replacement (je te suggère d'aller m'en acheter une autre!).

17) Mais qu'est-ce que c'est que ça? Tu as osé abimer ma plus belle veste! Je te suggère d'aller m'en acheter une autre!

'But what is this? You dared to destroy my best jacket! I suggest you buy a new.'

Appeals to the interlocutor's conscience appeared in the form of imperative utterances such as Gars sois un peu sérieux. 'Guy be a little serious.' Regarde un peu ça. 'Just look at this.' The example (18) provides an illustration of this type of preparatory act. The analysis reveals that some of these expressions of surprise in the data occurred in the middle or the end of a complaint turn, where they generally served as repetitions and upgraders of head acts. It also necessary to note that expressions like Ça c'est quoi ça? Gars c'est comment/how ? Mais qu'est-ce que ça veut dire ça? can also appear alone and function as complaints.

18) Regarde dans quel état tu me remets ma veste. Le fait qu'elle soit trouée ne te dérange même pas, ça alors. [Appeal to hearer's moral consciousness + Disappointmen + Exclamation]

'Look at the shape of my jacket you are returning to me. The fact that it has a hole does not even bother you. Wow."

\subsubsection{Attention getters}

They were used to catch the attention of the interlocutor. The participants employed expressions such as Je demande hein, Je dis hein, Je dis gars, Écoute Jacques, Attends, S'il te plait attends, combinations of interjections and nominal address terms such as Mais Ariane, Mais gars, Mais mon ami, Non Robert, Vraiment chère amie, etc. to draw the attention of the interlocutor. Attention getters occurred alone or in combination with other pre-complaints, as in (19-20).

19) Non Robert, ce n'est pas comme ça que je t'ai remis ma veste. Trouve une solution par rapport à ça.

'No Robert, this is not the condition in which I gave you my jacket. Find a solution to this issue.'

20) Gars, c'est how ? Qu'est-ce que ça veut dire? T'as vu ce que tu as fait de ma veste? Je ne peux plus la récupérer comme ça. Tu vas la remplacer seulement.

'Guy, what is this? What does this mean? Have you seen what you did to my jacket? I cannot take it back in this condition. You will have to replace it.' 
In (19), the preparatory act (in boldface) is made up of the opposition / negation marker non, which functions here as an interjection to signal disbelief, and the first name of the addressee (Robert). This combination is used to signal the speaker's surprise. The disbelief is also voiced in the head act (underlined), in which the speaker points at the damage on his jacket. In the third move, he asks the interlocutor to look for a solution: the speaker alludes to the problem and expects the hearer to solve it. In (20), the speaker prefaces his complaints with an address term (gars) and two expressions of surprise (in boldface). Interesting here is the code mixing C'est how? in lieu of C'est comment? to emphasize in-group identity before challenging the interlocutor's offensive behaviour. The complaint proper is the underlined utterance and it is followed by a rejection of the jacket in its current poor condition (Je ne peux plus la récupérer comme ça) and a request for replaeement ( $\mathrm{Tu}$ vas la remplacer seulement). The use of the adverb seulement in the request is meant to signal to the offender that the predicated action is the only solution that the speaker could imagine.

\subsubsection{Supportive acts}

According to Blum-Kulka et al. (1989c: 276), a supportive act is "a unit external to the [head act] which modifies its impact by either aggravating ... or mitigating ... its force". The speech acts used as supportive acts may focus on many different face-wants of the speaker or the addressee. The findings show that the respondents used different types of speech acts to modify their complaints. Table 4 summarizes the distribution of the supportive acts attested in the data.

Table 4: Distribution of supportive acts

\begin{tabular}{|l|c|}
\hline Type of supportive act & No (\%) \\
\hline Mentioning the value of the jacket & $16(21 \%)$ \\
\hline Expressing regret & $14(18.4 \%)$ \\
\hline Insistence act & $10(13.2 \%)$ \\
\hline Expressing sarcasm & $7(9.2 \%)$ \\
\hline Mitigating the damage - Suggesting solution & $25(32.9 \%)$ \\
\hline Invoking friendship & $4(5.3 \%)$ \\
\hline Total & $\mathbf{7 6 ( 1 0 0 \% )}$ \\
\hline
\end{tabular}

Overall, the respondents used 76 supportive acts: $47(61.8 \%)$ intensifying acts and $29(38.2 \%)$ mitigating acts. The supportive acts of both groups belong to different pragmatic sub-categories. There were four types of supportive acts with upgrading functions: mentioning the value of the jacket, expressing regrets, insistence acts, and expressing sarcasm. There were three types of supportive acts with mitigating functions: minimizing the damage, suggesting a solution, and invoking friendship. 'Mentioning the value of the jacket' (34\%) was the most preferred supportive act with intensifying function, while 'minimizing the damage' (86\%) was the most common supportive act with downgrading functions among the participants.

In the following, we will look at each individual supportive act in turn and highlight some of their realization patterns and pragmatic functions. We will start with supportive acts used as to aggravate complaints. 


\subsubsection{Mentioning the value of the jacket}

This supportive move aimed at intensifying the complaint by stressing the loss incurred, portraying the offender as irresponsible, and indirectly justifying the complaint made. Some respondents used declarative constructions in which they indicated that the jacket cost them a lot (e.g. Elle m'a coûté très cher. 'It cost me dearly.' Cette veste m'a énormément coûté. 'That jacket cost me a lot.' Sache qu'elle m'était vraiment chère. 'Know that it was very dear to me.' Elle m'a couté très cher et tu le sais. 'It cost me dearly and you know it'). Other participants made use of interrogative constructions with a rhetorical and/or a provocative undertone (e.g. Tu as conscience de ce que cette veste m'a coûté? 'Do you realize how much that jacket cost me?' Tu sais qu'elle m'a coûté cher non? 'You know it cost me dearly, right?'Est-ce que tu sais que cette veste m'a cô̂té cher? 'Do you that jacket cost me dearly?' Tu sais combien cette veste m'a coûté? 'Do you know how much that jacket cost me?') The participants also mentioned the symbolic or sentimental value attached the jacket, using constructions like C'était ma préférée. 'It was my favourite.' C'est la seule veste qui me reste. 'It's the only jacket I have left.' C'est la seule que j'ai. 'It's the only jacket that I have.' Toi-même tu connais sa valeur. 'You know its value quite well.'

\subsubsection{Expressing regret}

Many informants intensified their complaints by expressing regret for lending their jacket to their interlocutor. This strategy was realized in many different ways. The first realization type was the explicit performative constructions containing the verb regreter (e.g. Regarde comment tu me remercies. Je regrette pourquoi je t'ai prêté ma veste. 'Look how you thank me. I regret lending you my jacket.'). Some participants preferred constructions with verbs in the conditional (e.g. Je $n^{\prime}$ aurais jamais dî te la passer. 'I shouldn't have given it to you.' Si j'avais su que tu n'en prendras pas soin je ne te l'aurais pas prêtée. 'If I knew that you wouldn't take care of it, I wouldn't have lent it to you.'). Another realization type that occurred in the data consisted in describing the offence as a display of the interlocutor's habitual disappointing behaviour (e.g. Chaque fois que je te fais une faveur, je finis toujours par m'en mordre les doigts. 'Every time I do you a favour, I always end up disappointed.').

\subsubsection{Expressing sarcasm}

Sarcastic utterances were meant to express the opposite of what was literally said. In using this strategy, the respondents intended to stress their negative social attitude towards the offender. Most of the sarcastic utterances attested in the data were expressions of gratitude (e.g. Je te donne ma chose et toi tu pars la gâter merci beaucoup. 'I give you my thing and you destroy it. Thanks a lot.') There was one example in the data in which an expression of gratitude was employed alone to express an indirect complaint (Merci de m'avoir remis ma veste en bon état. 'Thanks for returning my jacket in good condition.').

\subsubsection{Insistence acts}

Some respondents used insistence acts to intensify their complaints. By using this move, which mostly appeared at the end of the complaint turn, the participants indicated that there was no alternative to be considered with respect to the content of the complaint act (e.g. a request for repair), as in (21), where the respondent used two acts of insistence, namely Je ne veux rien 
entendre. 'I don't want to hear anything.', C'est pas mon problème. 'It is not my problem.', to reinforce the preceding the complaint (Quand je t'ai prêté ma veste elle était en bon état) and the request for repair (Donc rends-la moi en bon état). The speaker in this example was saying: "no justification will make me change my mind". Other constructions used as insistence acts include je t'assure. 'I assure you.', rien à faire. 'No alternative.' plus jamais. 'Never'.

21) Quand je t'ai prêté ma veste elle était en bon état donc rends-la moi en bon état je ne veux rien entendre c'est pas mon problème.

'When I lent you my jacket, it was in good condition, so give it back to me in good condition, I don't want to hear anything, it is not my problem.'

\subsubsection{Minimizing the damage}

This supportive move was used by the informants to minimize the face threat of a complaint by describing the incident as accidental (C'était un accident) as in (22), or nothing (really) serious (Ce $n^{\prime} e s t$ pas (bien) grave) as in (23), or by telling their interlocutors not to worry (Ne t'inquiètes pas, $c^{\prime}$ est sans probleme) as in (22), or by announcing that they (the participants) were willing to take care of the repair or replacement of the damaged jacket as in (23-24).

22) Mon cher ami, j'ai remarqué la présence d'un grand trou au dos de ma veste. Ne vous inquiétez pas, c'est un accident comme les autres. C'est sans problème.

'My dear friend, I noticed a big hole on the back of my jacket. Don't worry, it is an accident like any other. No problem.'

23) Tu me mets vraiment en difficulté parce que c'est la seule que je possède. Mais ce n'est pas bien grave je pourrai acheter une autre.

'You really put me in a difficult situation because it is the only jacket I have. But that's okay. I can buy another one.'

24) Putain! Oh mon Dieu! Mais qu'est-ce qui a pu bien se passer? Frangin, tu as fait fort. Bon, on va gérer. On a l'habitude.

‘Damn, Oh my God! What really happened? Brother, you really screwed up. Well, we will manage the situation. We are used to such things.'

\subsubsection{Suggesting or Announcing a solution}

In order to soften their complaints, some respondents suggested a solution as in (25). This strategy served to restore the offender's positive face and to maintain a harmonious relationship.

25) Franchement mon ami je ne savais pas que tu pourrais mal entretenir ma veste. Comment es-tu arrivé à ce niveau? Mais ça va! Je vais l'arranger moi-même.

'Honestly my friend I didn't know you could be so careless with my jacket. How did you get to this level? But it's okay! I'll fix it myself.' 


\subsubsection{Invoking friendship and affection}

Mitigation of complaints was also performed by invoking friendship between the speaker and the addressee. More precisely, the participants employed this strategy to remind the interlocutors that their friendship was more valuable than the jacket in question as illustrated in (26-27).

26) Comment c'est arrivé ? C'est rien tu sais, l'amitié est un filon qui ne se brise qu'à la mort. Ce n'est donc pas pour une veste qu'on va se séparer.

'How did it happen? It's nothing you know, friendship is a vein that only breaks with death. So, it's not for a jacket that we're going to separate.'

27) Écoute Jacques, je te prends déjà comme un frère. Cette veste, elle est pour toi. Pas besoin de me la rendre.

'Listen Jacques, I already consider you as a brother. This jacket is for you. No need to return it to me.'

\section{Discussion and conclusion}

The results show that the respondents used of a wide variety of strategies to realize their complaints. As far as the structure of complaints utterances is concerned, it was found that complex complaint utterances were predominant in the data. The complexity of the utterances was due to the fact that the complaints (head acts) were either repeated or combined with a number of other speech acts with various pragmatic functions. The respondents preferred such complex utterances because there were suitable strategies to voices complaints while performing other face-saving/face-enhancing activities or even face-threatening activities.

Looking at the use of head acts, we noticed that the participants employed direct and indirect complaint strategies. Some of the complaint strategies aimed at expressing the participants' annoyance, disappointment, disapproval regarding the interlocutor's action, other strategies were employed to justify the respondents' disappointment, while a third group consisted of strategies meant to highlight the consequences of the complainer's anger, annoyance, disappointment. The analysis also revealed the use of many different types of devices to modify the complaint strategies both internally and externally. The internal modification devices most frequently employed were negatively loaded lexical elements such as adjectives, verbs, nouns, etc. and negatively loaded syntactic structures. With respect to external modifications of the complaints, the analysis revealed the use of a wide range of preparatory and supportive acts to intensify or soften complaint head acts. The results showed an abundant use of pre-complaints such as exclamations, nominal address terms, expressions of negative surprise and attention getters and the respondents' preference for supportive acts that aggravated their complaints. Overall, the study shows that most complaint strategies were not used in isolation. They were generally combined with other complaint strategies or speech acts to produce overall intensified or mitigated complaints.

Looking at some of the forms used to realize complaints (head acts), pre-complaints (e.g. exclamations and attention getters), and supportive moves, an interesting observation can be 
made. Complaint formulas in Cameroon French are generally marked by culturally and linguistically mixed patterns of communication: these include the combination of preparatory acts and head acts and the way in which disappointment is announced and supported; such choices may diverge, in some extent, from patterns employed in other French-speaking spaces. However, such differences may become evident in subsequent comparative analyses of complaint patterns across regional varieties of French.

Since the data for this study came from Cameroon French speakers' responses to DCT scenarios, one could argue that such examples would not reflect the choices made by the same respondents in natural occurring situations. Moreover, the study focused on data from one situation, so the results obtained here cannot be generalized to all situations. These examples, nevertheless, still reflect potential trends of Cameroon French speakers' complaint strategies and offer valuable insight into the complaint behaviour of French speakers in a postcolonial setting. There is need for more in-depth studies into this aspect of verbal interaction in French in Cameroon.

\section{Conflict of Interest Statement}

I declare that there is no conflict of interest in connection with the work submitted.

\section{About the Author}

The author is Full Professor of French and Linguistics at Cape Breton University, Canada. His main research interests include second / foreign language education, L2 French pragmatics, Language contact, Cross-cultural, Postcolonial, and Variational Pragmatics, Regional pragmatic variation in French.

\section{References}

Al-Khawaldeh, Nisreen (2016). A Pragmatic Cross-Cultural Study of Complaints Expressions in Jordan and England. International Journal of Applied Linguistics and English Literature, 5 (5), 197-207.

Anchimbe, Eric (2011). "Take a beer" - "Thanks, sorry, I prefer another day": A postcolonial pragmatic perspective on offers and offer refusals. In Joachim Frenk \& Lena Steveker (eds.), Anglistentag 2010 Saarbrücken Proceedings, 421-431. Trier: Wissenschaftlicher Verlag.

Boxer, Diana (2010). Complaint: How to gripe and establish rapport. In A. Martínez Flor and E. Usó Juan (Eds.), Speech act performance: Theoretical, empirical and methodological issues. (pp. 163-178). Amsterdam/New York: John Benjamins.

Boxer, D. (2010). Complaints: How to Gripe and Establish Rapport. In Martinez-Flor, A. \&UsoJuan, E. (2010). Speech Act Performance: Theoretical and Methodological Issues. co.

Boxer, D. (1993a). Complaining and Commiserating. A Speech Act View of Solidarity in Spoken American English. New York: Peter Lang.

Boxer, D. (1993). Social distance and speech behavior: The case of indirect complaints. Journal of Pragmatics, 19(2), 103-125. 
Dersley, I. and Wootton, A. (2000). Complaint Sequences within Antagonistic Argument, Research on Language and Social Interaction 33: 375-406.

Drew, P. (1998). Complaints about Transgressions and Misconduct, Research on Language and Social Interaction 31: 295-325.

Essien Otung, Glory (2019). Campus Decorum: The realisation of apologies, complaints and requests by Nigerian and German students. M.A thesis, University of Bayreuth.

Geluykens R. \& Kraft, B. (2003). Sociocultural variation in native and interlanguage complaints. In: K. Jaszcolt \& K. Turner (Eds.): Meaning Through Language Contrast (pp. 251-261). Amsterdam/New York: Benjamins.

Geluykens, R. \& Bettina Kraft, B. (2006). Eine Kontrastive Analyse des Beschwerdeverhaltens in Deutsch und Französisch als Muttersprache und Lernersprache. Zeitschrift der Gesellschaft für Sprache und Sprachen, 33-34, 3-13.

Laforest, Marty (2002). Scenes of family life: Complaining in everyday conversation. Journal of Pragmatics, 34 (10-11), 1595-1620.

Marchand, Ruben (2016). Kundenbeschwerden auf den Twitterprofilen der Deutschen Bahn und der SNCF: eine pragmatische und cross-kulturelle Analyse. Master's Thesis. University of Gent.

Meinl, M. (2010). Electronic Complaints: An Empirical Study on British English and German Complaints on eBay. (Dissertation). University of Bonn.

Meyer, Katrin (2007). Interkulturelle Pragmatik: Aufforderungen, Entschuldigungen und Beschwerden. (Dissertation), University of Hamburg.

Murphy, B. \& Neu, J. (1996). My grade's too low: The speech act set of complaining. In S. M. Gass and J. Neu (Eds.), Speech acts across cultures: Challenges to communication in a second language, (191-216). Berlin: Walter de Gruyter.

Ohlstain E. \& Weinbach L. (1987). Complaints: a study on speech act behaviour among native and non-native speakers of Hebrew. In Bertucelli-Papi, Marcella and Verschueren, Jef (Eds.), The Pragmatic Perspective: Selected Papers from the 1985 International Pragmatics Conference. Amsterdam/Philadelphia: Benjamins.

Olshtain, E., \& Weinbach, L. (1993). Interlanguage features of the speech act of complaining. In G. Kasper \& S. Blum-Kulka (Eds.), Interlanguage Pragmatics (pp. 108-122). Oxford: Oxford University Press.

Trosborg, A. (1995). Interlanguage Pragmatics: Requests, Complaints and Apologies. Berlin New York: Mouton de Gruyter.

Vasquez, C. (2011). Complaints online: The case of TripAdvisor. Journal of Pragmatics, 43 (6), 1707-1717. 
Author(s) will retain the copyright of their published articles agreeing that a Creative Commons Attribution 4.0 International License (CC BY 4.0) terms will be applied to their work. Under the terms of this license, no permission is required from the author(s) or publisher for members of the community to copy, distribute, transmit or adapt the article content, providing a proper, prominent and unambiguous attribution to the authors in a manner that makes clear that the materials are being reused under permission of a Creative Commons License. Views, opinions and conclusions expressed in this research article are views, opinions and conclusions of the author(s). and European Journal of Literature, Language and Linguistics Studies shall not be responsible or answerable for any loss, damage or liability caused in relation to/arising out of conflicts of interest, copyright violations and inappropriate or inaccurate use of any kind content related or integrated into the research work. All the published works are meeting the Open Access Publishing requirements and can be freely accessed, shared, modified, distributed and used in educational, commercial and non-commercial purposes under a Creative Commons Attribution 4.0 International License (CC BY 4.0). 